\title{
Characterization of Three Group A Klebicin Plasmids: Localization of Their E Colicin Immunity Genes
}

\author{
By RICHARD JAMES, * JORG SCHNEIDER† AND PEARL C. COOPER \\ School of Biological Sciences, University of East Anglia, Norwich NR4 7TJ, UK
}

(Received 23 March 1987)

\begin{abstract}
We have investigated the immunity to $\mathrm{E}$ colicins conferred by three group $\mathrm{A}$ klebicin plasmids. pP5a, which encodes klebicin A1-P5, like pClo-DF13, confers immunity to colicin E6 on Escherichia coli K12, whilst pP5b and pP3, which encode klebicins A2-P5 and A3-P3 respectively, both confer immunity to colicin E3. We have determined the restriction endonuclease and functional maps of the three group A klebicin plasmids. By sub-cloning and transposon mutagenesis we have investigated the relationship between the klebicin immunity and the E colicin immunity conferred by these plasmids. The colicin E6 and the klebicin Al immunity are encoded by a single gene present on pP5a. The colicin E3 and the klebicin A2 immunity are encoded by a single gene present on pP5b. The colicin E3 and the klebicin A3 immunity are encoded by separate genes present on pP3. Recombinant pML8412, which is derived from the ColE6-CT14 plasmid and encodes colicin E6 immunity, confers klebicin AlP5 immunity upon Klebsiella pneumoniae UNF5023. Recombinant pKC23, which is derived from the ColE3-CA38 plasmid and confers colicin E3 immunity, confers immunity to klebicin A2-P5, but not to klebicin A3-P3.
\end{abstract}

\section{INTRODUCTION}

The E colicins are a group of plasmid-encoded, antibacterial proteins which use the same cellsurface receptor to bind to sensitive Escherichia coli cells (Di Masi et al., 1973). This group has been subdivided into colicins E1 to E9 on the basis of immunity tests (Watson et al., 1981; Cooper \& James, 1984). Each E colicin plasmid codes for the production of a specific immunity protein, which protects colicin-producing cells from colicin of the same type. E. coli $\mathrm{K} 12$ strains carrying an $\mathrm{E}$ colicin plasmid are sensitive to mitomycin $\mathrm{C}(\mathrm{MC})$, and thus differ from plasmidfree isogenic strains, due to the induction of a plasmid-coded lysis gene (lys) which is involved in colicin release from the producing cell (Shafferman et al., 1979; Pugsley \& Schwartz, 1983; Suit et al., 1983; Chak \& James, 1984, 1986; Jakes \& Zinder, 1984; Lawrence \& James, 1984). Since immunity is constitutively expressed, whilst colicin production and MC sensitivity are inducible by DNA damage (Herschman \& Helinski, 1967), the regulatory control of these three genes is of considerable interest.

The genetic organization of the ColE3-CA 38 plasmid has been extensively characterized. The colicin E3 structural gene $(\mathrm{ceaC})$ and the $l y s$ gene $(\mathrm{celC})$ are transcribed from a common SOS promoter located proximal to the structural gene, whilst the ColE3imm gene $(\mathrm{ceiC})$, which is located between these two genes, has its own promoter (Chak \& James, 1984; Jakes \& Zinder, 1984; Mock et al., 1984). We have identified a second gene, conferring immunity to colicin E8 (ceiH), located in tandem with the ColE3imm gene (Chak \& James, 1984), the nucleotide sequence of which has subsequently been reported (Lau et al., 1984). The ColE8imm gene also has its own promoter (Chak \& James, 1985). It has been suggested that the ColE3-CA38 plasmid

† Present Address: Fachbereich Biologie, Technischen Hochschule, Darmstadt, West Germany.

Abbreviations: MC, mitomycin C; Xgal, 5-bromo-4-chloro-3-indolyl $\beta$-D-galactopyranoside; ORF, open reading frame. 
may represent a plasmid 'caught in the act of evolution' (Lau et al., 1984), but the recent findings of further tandem immunity genes, against colicin E8 in the ColE6-CT14 plasmid (Lawrence, 1984) and against colicin E5 in the ColE9-J plasmid (Chak \& James, 1986), suggest that the ColE3-CA38 plasmid is far from unique.

Recently we analysed a number of producer strains in the Edmondson \& Cooke (1979) klebicin typing panel and described three klebicin A plasmids, pP5a, pP5b and pP3, which encode klebicins A1-P5, A2-P5 and A3-P3 respectively (Cooper \& James, 1985). All three of these klebicins use the same cell-surface receptor to kill sensitive cells of Klebsiella pneumoniae, but can be differentiated by the absence of cross-immunity. Klebicin A1-P5 belongs to the same immunity group as cloacin DF13 (Oudega et al., 1979). pCloDF13 confers colicin E6 immunity on E. coli K12 (Males \& Stocker, 1982), but it is not known whether the colicin E6 immunity is encoded by the same gene as that which confers cloacin DF1 3 immunity. Since $K$. pneumoniae strains are not killed by $E$ colicins, presumably due to the absence of the $b t u B$ receptor, whilst $E$. coli K12 strains lack the aerobactin receptor (Van Tiel-Menkveld et al., 1981) and are therefore not killed by group A klebicins (Cooper \& James, 1985), it is perhaps surprising that the CloDF 13 plasmid confers immunity to an E colicin, unless the two immunities are encoded by a single gene. We have investigated the $\mathrm{E}$ colicin immunities conferred by the group $\mathrm{A}$ klebicin plasmids. We have used gene-cloning and transposon mutagenesis to determine the restriction and functional maps of the group A klebicin plasmids, and to study the relationships between their E colicin and klebicin immunity genes. Similar information has been invaluable in the study of the evolutionary relationships between the E group colicins (Watson et al., 1985: Chak \& James, 1986).

\section{METHODS}

Bacterial strains and plasmids. The strains of $K$. pneumoniae used in this work are listed in Table $1 . E$. coli $\mathrm{JM} 83 h s d R$ is a restriction-deficient derivative of $E$. coli $\mathrm{JM} 83 \mathrm{Ara}^{+} \mathrm{Lac}^{-} \mathrm{Pro}^{-} \mathrm{Thi}^{-}$rps $L \phi 80 \mathrm{~d} l a c Z \mathrm{M} 15$. E. coli JM105 Lac ${ }^{-}$Pro-Thi ${ }^{-}$rpsL. F'traD lacI'/acZM15 was supplied by Gibco-BRL. Plasmids pP5a, pP5b and pP3 were prepared from strains PC905, PC909 and PC910 respectively (Cooper \& James, 1985).

Media. Bacteria were cultured at $37^{\circ} \mathrm{C}$ in L broth (Miller, 1972). The chromogenic substrate 5-bromo-4-chloro3-indolyl $\beta$-D-galactopyranoside (Xgal) was included in $\mathrm{L}$ agar ( $\mathrm{L}$ broth containing $1.5 \%$, $\mathrm{w} / \mathrm{v}$, agar) at a final concentration of $20 \mu \mathrm{g} \mathrm{ml}^{-1}$ to detect recombinant plasmids. Ampicillin (Ap) was included in all media, at a final concentration of $100 \mu \mathrm{g} \mathrm{ml}^{-1}$ for the growth of all $E$. coli $\mathrm{K} 12$ strains which carried recombinant plasmids, and at a final concentration of $200 \mu \mathrm{g} \mathrm{ml}^{-1}$ for all Klebsiella strains which carried recombinant plasmids.

Klebicin production and immunity tests. Klebicin production was determined by stab tests (Ozeki et al., 1962), using $K$. pneumoniae UNF5023 as the sensitive indicator strain. Klebicin immunity was determined by overlaying stabs of PC905, PC909 and PC910 with lawns of $K$. pneumoniae UNF5023 carrying the test plasmid. E colicin immunity was determined by streaking cultures of $E$. coli JM83 hsdR carrying the test plasmid on LB agar plates

\section{Table 1. Bacterial strains and plasmids}

Relevant properties

Source or derivation

K. pneumoniae

UNF5023

PC905

PC909

PC910

Plasmid

pJN73

pUC8

pUC18

pUC19

pML8412

pKC23

pLAX4

p3294

pKH3-8 his hsdR rpsL

UNF5023(pP5a)

UNF5023(pP5b)

UNF5023(r64-11)(pP3)

pClo-DF13:: Tn901, cloacin production and immunity, $A \mathrm{p}^{\mathrm{R}}$

$\mathrm{Ap}^{\mathrm{R}}$

$A p^{R}$

$\mathrm{Ap}^{\mathrm{R}}$

ColE6imm, $A p^{R}$

ColE3imm, Ap ${ }^{R}$

ColE3imm, Ap ${ }^{R}$

Bal31 deletion mutant of pLAX4, ColE3 3

bruB $B^{+}, \mathrm{Ap}^{\mathrm{R}}$
M. Merrick

Cooper \& James (1985)

Cooper \& James (1985)

Cooper \& James (1985)

B. Oudega

J. Messing

J. Messing

J. Messing

Lawrence (1984)

Chak \& James (1984)

Mock et al. (1983)

Mock et al. (1983)

R. Kadner 
spread with E. colicin extracts prepared as described previously (Chak \& James, 1984). Each test was done on at least six isolates from each test culture to determine the phenotype encoded by each recombinant plasmid.

Plasmid isolation, restriction, ligation, transformation and electrophoresis. All plasmids were prepared by a modification of the method of Birnboim \& Doly (1979). The methods for restriction, ligation, transformation and electrophoresis of plasmid DNA have been described previously (Chak \& James, 1984). ClaI linker was obtained from Gibco-BRL and was used as described previously (Maniatis et al., 1982).

Co-transformation. In the absence of a good positive selection for the transformation of the three group $A$ klebicin plasmids into $E$. coli, we used a co-transformation procedure. The native group A klebicin plasmids were transferred into $E$. col $i \mathrm{JM} 83 h s d R$ by transforming with a mixture of pUC8 vector and the native klebicin plasmid in a ratio of $1: 10$. The relative DNA concentrations of the respective plasmids were estimated by a comparison of their band intensities after agarose gel electrophoresis. Transformants were selected on Ap-containing plates and were then screened for klebicin production.

Transposon mutagenesis. This was done with $\mathrm{Tn} / 000$ as described previously (Chak \& James, 1984). The insertion sites of $\mathrm{Tn} 1000$ were determined by restriction with EcoRI, BamHI and HindIII (Guyer, 1978).

Electrophoresis of klebicins. Cultures of $K$. pneumoniae UNF5023 carrying appropriate plasmids were grown in L broth to an $\mathrm{OD}_{550}$ of 0.2 before the addition of $\mathrm{MC}\left(0.5 \mu \mathrm{g} \mathrm{ml}^{-1}\right)$ to half of each culture to induce the synthesis of klebicins. After $2 \mathrm{~h}$ further incubation, $1 \mathrm{ml}$ of each culture was removed and the cells were recovered by centrifugation. The cell pellet was resuspended in $100 \mu \mathrm{l}$ electrophoresis sample buffer, heated to $100^{\circ} \mathrm{C}$ for $5 \mathrm{~min}$ and then centrifuged again. Portions $(25 \mu \mathrm{l})$ of the total cell proteins were then analysed by SDS-PAGE (Laemmli, $1970)$ in $10^{\circ}(\mathrm{w} / \mathrm{v})$ gels using standard proteins as molecular mass markers. This experiment was repeated twice with identical results.

Hybridization. Specific fragments to be used as hybridization probes were isolated from low-melting-point agarose and labelled with [ ${ }^{35}$ S)CTP (Amersham) using a Multiprime kit (Amersham), following the supplier's instructions. Restricted plasmids were tested for their hybridization with the probes after Southern blotting onto nitrocellulose filters. Hybridization was done at $68^{\circ} \mathrm{C}$ for $16 \mathrm{~h}$ in the absence of formamide as described by Maniatis et al. (1982).

\section{RESULTS AND DISCUSSION}

\section{E colicin immunities conferred by A klebicin plasmids}

The native group A klebicin plasmids were transferred to $E$. coli JM83hsdR by cotransformation with pUC8. Representative $A p^{R}$ colonies which carried $p U C 8$, with either pP5a, pP5b, pP3 or no plasmid, were then tested for their immunity to E colicins (Table 2). E. coli JM83 hsd $R$ which had been transformed with pJN73, a CloDF13 plasmid which carries Tn901 inserted in a non-essential region of the plasmid (Andreoli et al., 1978), was included as a control. The results clearly show that pP5a, like CloDF13, confers colicin E6 immunity, whilst the pP5b and the pP3 plasmids confer colicin E3 immunity. In order to study the relationship between the respective klebicin and colicin immunity phenotypes conferred by the group $\mathrm{A}$ klebicin plasmids we used molecular cloning techniques and transposon mutagenesis.

\section{Cloning of the klehicin A1-P5 plasmid}

Preliminary restriction mapping of native pP5a indicated considerable similarity with pCloDF 13 (data not shown). We cloned Sall-restricted pP5a DNA into the Sall site of vector pUC8 and then transformed $E$. coli JM83hsdR to Ap resistance. The white transformant colonies on Xgal/Ap plates were tested for klebicin production. Recombinant pRJ119 was isolated from a klebicin-encoding transformant but this plasmid, which contained the whole $9.8 \mathrm{~kb}$ pP5a plasmid, was unstable. We have been unable to construct a stable recombinant plasmid which produces klebicin A1-P5. Restriction of pP5a DNA with BamHI yields two fragments of $8.3 \mathrm{~kb}$ and $1.5 \mathrm{~kb}$. Ligation of BamHI-restricted pP5a DNA witi BamHI-restricted pUC8, and subsequent transformation of E. coli JM83 hsd R to Ap ${ }^{\mathrm{R}}$ and colicin E6 immunity, yielded transformant colonies which carried $\mathrm{pRJ} 118$. On testing, this recombinant plasmid did not encode klebicin production. Restriction of pRJ118 with BamHI yielded fragments of $8.3 \mathrm{~kb}$ and $2.7 \mathrm{~kb}$. These results indicate that the klebicin Al-P5 structural gene is at least partially located within the $1.5 \mathrm{~kb} \mathrm{BamHI}$ fragment of pP5a. A similar location has previously been reported for the cloacin DF13 structural gene on the Clo-DF13 plasmid (Hakkaart et al., 1981). A restriction map of $\mathrm{pRJ} 118$ is shown in Fig. 1 . pRJ118 was transformed into $K$. pneumoniae 


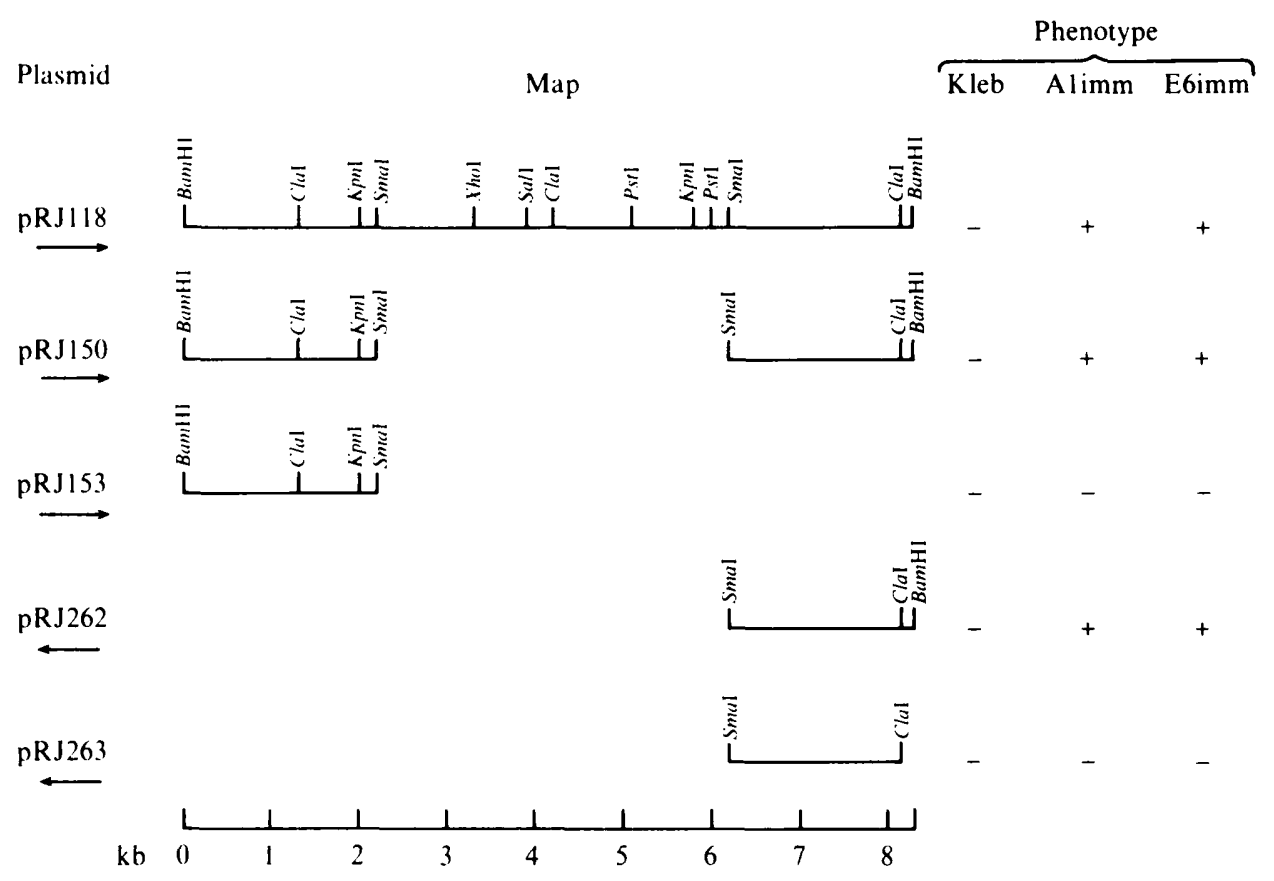

Fig. 1. Restriction map and sub-clones of pP5a. The restriction fragments present in the plasmids listed are indicated (for clarity the vector sequences are not shown) together with the phenotypes conferred. The arrows indicate the direction of transcription through the insert fragment initiated from the vector lac promoter.

Table 2. E colicin immunities conferred by group A klebicin plasmids

The plasmid present in the indicator strain is shown in parentheses. + , indicator is sensitive to the colicin extract; - , indicator is insensitive to the colicin extract.

\begin{tabular}{lcccccccc}
\multicolumn{10}{c}{ Sensitivity to colicins } \\
\cline { 2 - 6 } Indicator strain & E2 & E3 & E4 & E5 & E6 & E7 & E8 & E9 \\
JM83(pJN73) & + & + & + & + & - & + & + & + \\
JM83(pP5a) & + & + & + & + & - & + & + & + \\
JM83(pP5b) & + & - & + & + & + & + & + & + \\
JM83(pP3) & + & - & + & + & + & + & + & + \\
JM83 & + & + & + & + & + & + & + & +
\end{tabular}

UNF5023 and a representative colony was tested to confirm that klebicin A1-P5 immunity was encoded by this plasmid. $K$. pneumoniae cultures carrying pRJ118 were, however, sensitive to klebicins A2-P5 and A3-P3.

In an attempt to localize the klebicin Al-P5 immunity gene and the colicin E6 immunity gene, we constructed a series of sub-clones of pRJ118 (Fig. 1). The phenotypes conferred by recombinant plasmids pRJ150 and pRJ153 suggest that the colicin E6 and the klebicin A1 immunity genes are located in the $2.2 \mathrm{~kb} S m a \mathrm{I}-$ Bam HI fragment of pP5a. This was confirmed by deletion of the $2.1 \mathrm{~kb} B a m \mathrm{HI}-S m a \mathrm{I}$ fragment of $\mathrm{pRJ} 150$ by restriction with BamHI and SmaI and subsequent religation. The resulting plasmid, pRJ262, conferred immunity to colicin E6 upon $E$. coli JM105. During the construction of pRJ262 from pRJ150, the orientation of the insert fragment is reversed with respect to the vector lac promoter. This required the use of $E$. coli JM105 as a host strain for transformation in order to repress the lac promoter of the vector, since we had previously observed that the $2 \cdot 2 \mathrm{~kb} S m a \mathrm{I}-$ Bam $\mathrm{HI}$ fragment could not be cloned in 
E. coli JM83 when the vector promoter was transcribing this fragment in this orientation. pRJ262 conferred an IPTGS phenotype upon $E$. coli JM105, presumably, by analogy with the genetic organization of cloacin DF13 and other group E colicins, due to constitutive expression of the lys gene present in this DNA fragment. Upon transformation into $K$. pneumoniae UNF5023, pRJ262 conferred klebicin Al immunity. For these immunity tests, $K$. pneumoniae UNF5023(pRJ262) cultures were grown in L broth supplemented with glucose to reduce the expression of the vector lac promoter. In the absence of glucose, growth of these cultures was poor and $\mathrm{Ap}^{\mathrm{s}}$ segregants were readily observed.

The precise localization of the colicin E6 imm gene was determined by deletion of the $300 \mathrm{bp}$ ClaI fragment of pRJ262, from the single ClaI site in the insert fragment to a ClaI site in the vector, introduced by inserting a ClaI linker into the HincII site of the vector. The resulting plasmid pRJ263 did not confer E6 immunity upon E. coli JM105, although it still exhibited the IPTG ${ }^{S}$ phenotype, indicating that the vector promoter was still transcribing through the insert fragment. When transformed into $K$. pneumoniae UNF5023, again in the presence of glucose, pRJ 263 did not confer klebicin Al immunity. This result is in agreement with the localization of the cloacin DF13 immunity gene (Hakkaart et al., 1981) and confirms that the colicin E6 immunity and the klebicin Al immunity genes are identical.

\section{Cloning of the klebicin A2-P5 plasmid}

Restriction mapping of the native $7.5 \mathrm{~kb}$ pP5b plasmid indicated the presence of a single $B g l$ II site (data not shown). We cloned BglII-restricted pP5b DNA into the BamHI site of vector pUC8 and then transformed $E$. coli JM83 hsdR to Ap ${ }^{\mathrm{R}}$. Plasmid pRJ132 was isolated from a recombinant clone which produced klebicin A2-P5 and conferred immunity to colicin E3. After transfer to $K$. pneumoniae UNF5023 by transformation, plasmid pRJ132 conferred klebicin A2P5 immunity. Restriction mapping confirmed that this plasmid consisted of the whole pP5b plasmid cloned into the BamHI site of the vector. In an attempt to locate the klebicin A2-P5 structural gene and the two immunity genes, we constructed a series of sub-clones of plasmid pRJ132 (Fig. 2). The phenotype conferred by plasmid pRJ155 localizes the three genes of interest to the $4.3 \mathrm{~kb} X h o I-B g / \mathrm{II}$ fragment of pP5b. Klebicin production was inactivated by deletion of the $1.5 \mathrm{~kb}$ BamHI fragment of pRJ155. The resulting plasmid, pRJ159, still conferred klebicin A2-P5 and colicin E3 immunity. The phenotypes conferred by plasmids pRJ164 and pRJ244 localize the two immunity genes to the 600 bp SphI-BamHI fragment of pP5b. Tn 1000 mutagenesis of pRJ155 confirmed that the two immunity genes must have a separate promoter(s) to the klebicin structural gene as four independent transposon inserts located at $1.5 \mathrm{~kb}, 1.7 \mathrm{~kb}, 1.9 \mathrm{~kb}$ and $2.4 \mathrm{~kb}$ all inactivated the klebicin structural gene but did not affect either immunity phenotype (Fig. 2). This identifies a minimum region coding for the klebicin A2-P5 gene of $900 \mathrm{bp}$, sufficient to code for a protein of $33 \mathrm{kDa}$. Using plasmid pRJ164, all $\mathrm{Tn} 1000$ inserts which inactivated the colicin E3 immunity phenotype also inactivated klebicin A2-P5 immunity. The site of insertion of three of these inserts in pRJ164 is shown in Fig. 2. In a modified Tn 1000 mutagenesis experiment we transformed $K$. pneumoniae UNF5023 with plasmid DNA prepared from 36 randomly selected transconjugant $E$. coli colonies. Single, representative transformant colonies were grown up in LB containing Ap and then tested for sensitivity to klebicin A2-P5. The transposon insertion sites of six klebicin A2 sensitive transformants were all located in the right-hand $350 \mathrm{bp}$ of the $950 \mathrm{bp} \mathrm{XhoI-BamHI}$ fragment of pRJ164. After transformation of these six plasmids into $E$. coli JM83 $h s d R$, all of the resulting transformants were colicin E3 sensitive. This result strongly suggests that the colicin E3imm gene and the klebicin A2imm gene are identical.

\section{Cloning of the klebicin A3-P3 plasmid}

Restriction mapping of the native $12.5 \mathrm{~kb}$ pP3 plasmid indicated the presence of two HindIII sites, yielding fragments of 7.0 and $5.5 \mathrm{~kb}$. We cloned HindIII-restricted pP3 DNA into the $H$ indIII site of pUC 18 and transformed $E$. coli $\mathrm{JM} 83 h s d R$ to $\mathrm{Ap}^{\mathrm{R}}$ and colicin E3 ${ }^{\mathrm{R}}$. pRJ 157 was isolated from a recombinant clone which produced klebicin A3-P3 and was immune to colicin E3. After transfer to K. pneumoniae UNF5023, this plasmid conferred immunity to klebicin A3- 


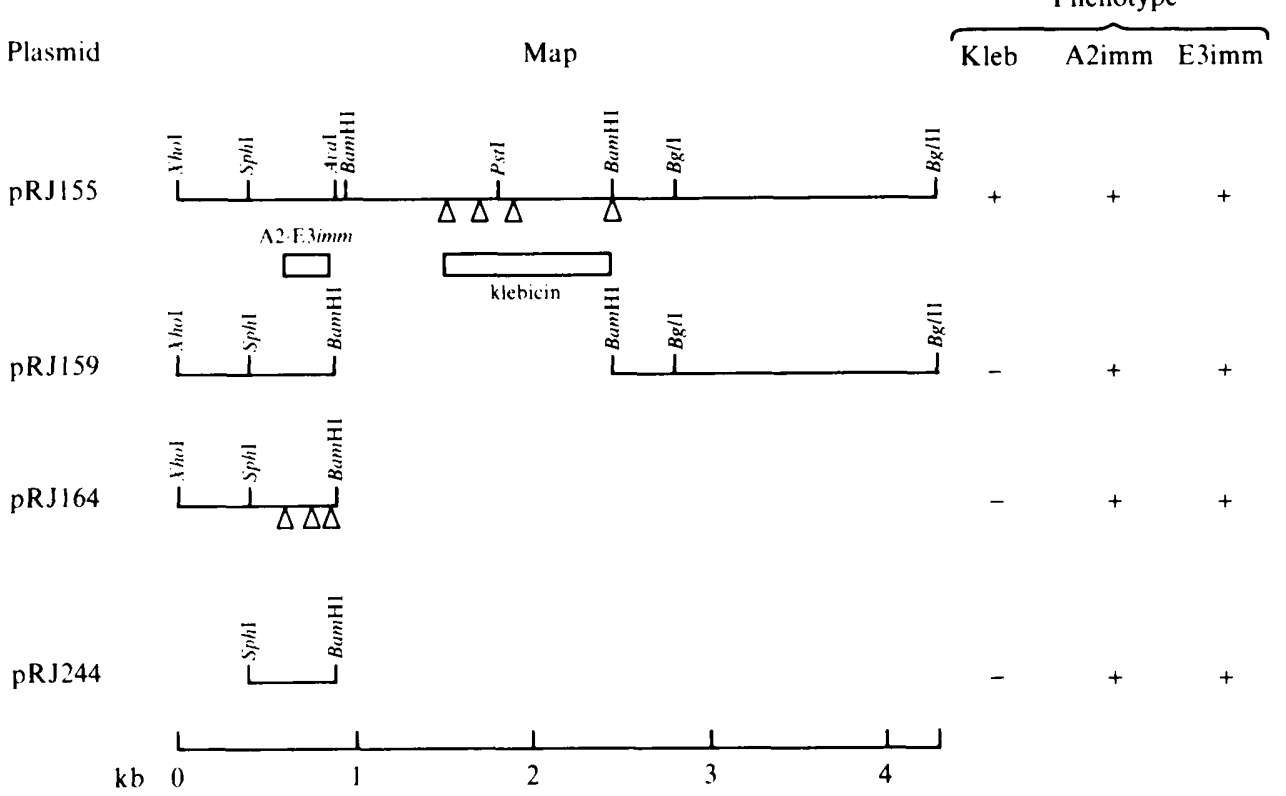

Fig. 2. Restriction map and sub-clones of pP5b. The restriction fragments present in the plasmids listed are indicated together with the phenotypes conferred. $\mathrm{Tn} 1000$ insertion sites which inactivate the klebicin A2-P5 gene of $\mathrm{pRJ} 155$ or the E3imm gene of pRJ164 are indicated by triangles on the restriction map of the relevant plasmid. The minimum sizes of the klebicin and the A2imm gene, determined from the $\operatorname{Tn} 1000$ data, are indicated by boxes.
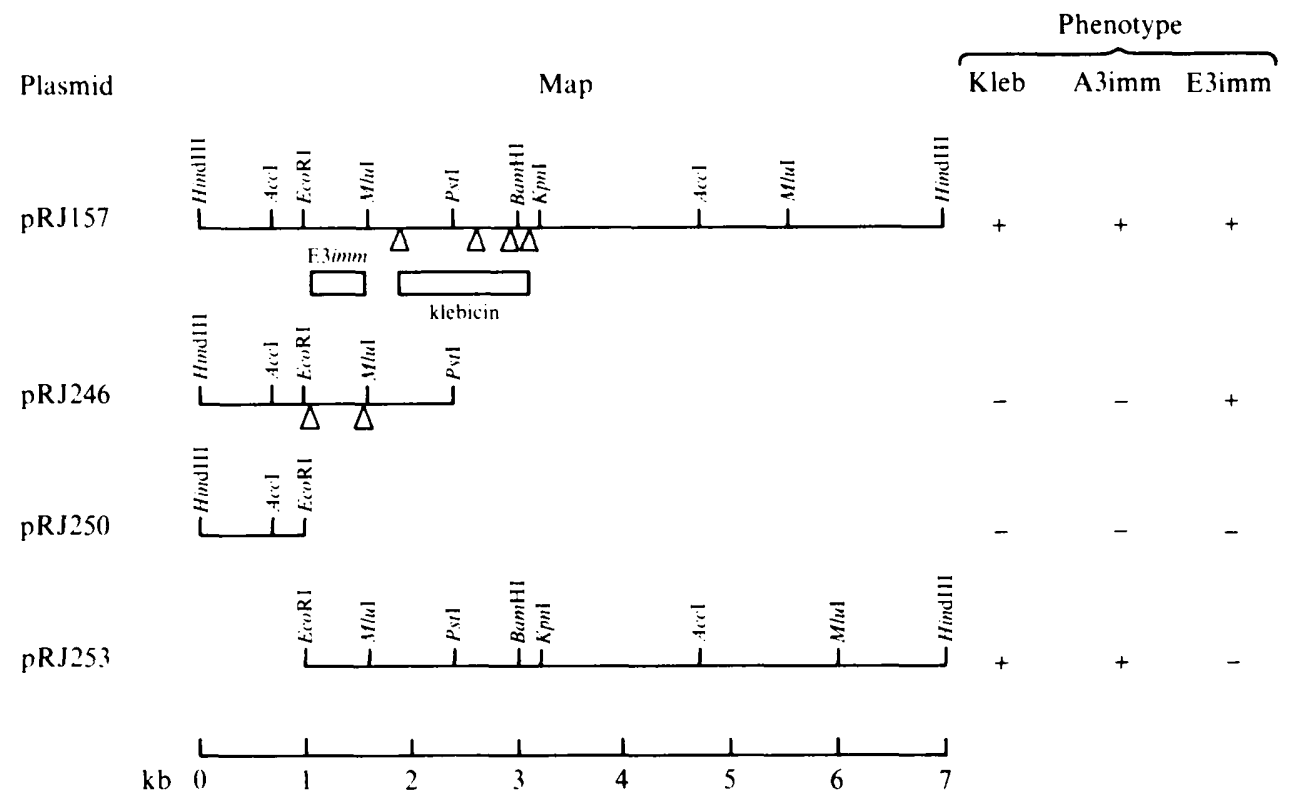

Fig. 3. Restriction map and sub-clones of $\mathrm{pP} 3$. The restriction fragments present in the plasmids listed are indicated together with the phenotypes conferred. Tn 1000 insertion sites which inactivate the klebicin A3-P3 gene of pRJ157 or the E3imm gene of pRJ246 are indicated by triangles. The minimum sizes of the klebicin and the E3imm genes, determined from the Tn 1000 data, are indicated by boxes. 
Table 3. Klebicin immunities conferred by E colicin immunity genes

The plasmid present in the indicator strain is shown in parentheses. + , a zone of inhibition was present around the producing stab; -, no zone of inhibition.

\begin{tabular}{lccc} 
Indicator strain & \multicolumn{3}{c}{ Sensitivity to klebicins } \\
\cline { 2 - 2 } & A1-P5 & A2-P5 & A3-P3 \\
UNF5023(pKC23) & + & + & + \\
UNF5023(pLAX4) & + & - & + \\
UNF5023(p3294) & + & - & + \\
UNF5023 & + & + & +
\end{tabular}

P3, but not to klebicin A1-P5 or to klebicin A2-P5. Restriction mapping confirmed that pRJ157 consisted of the $7 \mathrm{~kb}$ HindIII fragment of pP3 cloned into the HindIII site of pUC18. In an attempt to localize the klebicin A3-P3 structural gene and the two immunity genes we constructed a series of sub-clones of pRJ157 (Fig. 3). The phenotype conferred by plasmids pRJ 246 and pRJ 250 indicates that the E3imm gene must lie in the $1.35 \mathrm{~kb} E c o \mathrm{RI}-P$ st I fragment of $\mathrm{pRJ} 246$. The phenotype conferred by $\mathrm{pRJ} 253$ shows that the E3imm gene is distinct from the klebicin A3imm gene and that the E3imm gene is cut by EcoRI. Tn 1000 inserts located at $1.9 \mathrm{~kb}$, $2.6 \mathrm{~kb}, 2.95 \mathrm{~kb}$ and $3.15 \mathrm{~kb}$ in pRJ157 inactivated klebicin A3-P3 production (Fig. 3). This identifies a region of $1.25 \mathrm{~kb}$ as the minimum size of the klebicin A3-P3 structural gene, sufficient to encode a protein of $46 \mathrm{kDa}$. The Tn 1000 inserts located at $2.6 \mathrm{~kb}, 2.95 \mathrm{~kb}$ and $3.15 \mathrm{~kb}$ did not affect klebicin A3 or colicin E3 immunity; however, the insert at $1.9 \mathrm{~kb}$ abolished klebicin A3 immunity but not colicin E3 immunity. This suggests that the klebicin A3 immunity gene promoter is located between $1.9 \mathrm{~kb}$ and $2.6 \mathrm{~kb}$. This is in agreement with the phenotype conferred by pRJ246, in which the klebicin A3 immunity gene promoter has presumably been deleted. Transposon inserts located at $3.8 \mathrm{~kb}$ and $4.3 \mathrm{~kb}$ in pRJ246 inactivated the E3imm gene. Although we have no direct evidence, by analogy with the genetic organization of other bacteriocins it may be reasonable to assume that the A $3 \mathrm{imm}$ gene is located between the klebicin structural gene and the E3imm gene.

\section{Klebicin immunity conferred by E colicin plasmids}

In view of the $\mathrm{E}$ colicin immunity conferred by the $\mathrm{A}$ klebicin plasmids and the probability, in the case of the pP5a and the pP5b plasmids, that the colicin and klebicin immunity genes are identical, we investigated the klebicin immunity conferred by recombinant plasmids which carry defined regions of E colicin plasmids. Recombinant pML8412 consists of the $1.2 \mathrm{~kb}$ ClaIEcoRI fragment of pColE6-CT14 cloned into pBR322 restricted with ClaI and EcoRI (Lawrence, 1984). This plasmid confers colicin E6 immunity on E. coli $\mathrm{K} 12$ and klebicin A1-P5 immunity on $K$. pneumoniae UNF5023 (Table 3), and thus supports our findings that these two immunity proteins are encoded by a single gene. pKC23 consists of the $1.0 \mathrm{~kb}$ Eco RI-ClaI fragment of pColE3-CA38 cloned into pBR322 restricted with EcoRI and ClaI (Chak \& James, 1984). This plasmid confers colicin E3 immunity on E. coli $\mathrm{K} 12$ and klebicin A2-P5 immunity on $K$. pneumoniae UNF5023; however, pKC23 does not confer immunity to klebicin A3-P3. Inspection of the nucleotide sequence of the $1 \mathrm{~kb} C l a I-E c o R I$ fragment of pColE3-CA 38 has shown the presence of a second open reading frame (ORF) at the $3^{\prime}$ end of the colicin E3 structural gene. This ORF directs the synthesis of an $11 \mathrm{kDa}$ protein in vitro (Mock et al., 1983). To exclude the possibility that it is this ORF which encodes the klebicin A2 immunity protein we examined the phenotype conferred by p3294, which is a Bal31 deletion from the EcoRI site of pLAX4, a plasmid identical to pKC23 (Mock et al., 1983, 1984). p3294, which has lost the E3imm gene as a result of the Bal31 deletion and still directs the synthesis of the $11 \mathrm{kDa}$ protein in vitro (Mock et al., 1983), does not confer immunity to klebicin A2-P5 (Table 3). These results strongly suggest that the E3imm gene of pColE3-CA38 and the klebA2imm gene of pP5b are capable of conferring immunity to both colicin E3 and klebicin A2-P5. Since immunity is very specific, this implies that the killing activities of the two bacteriocins are very similar, if not 


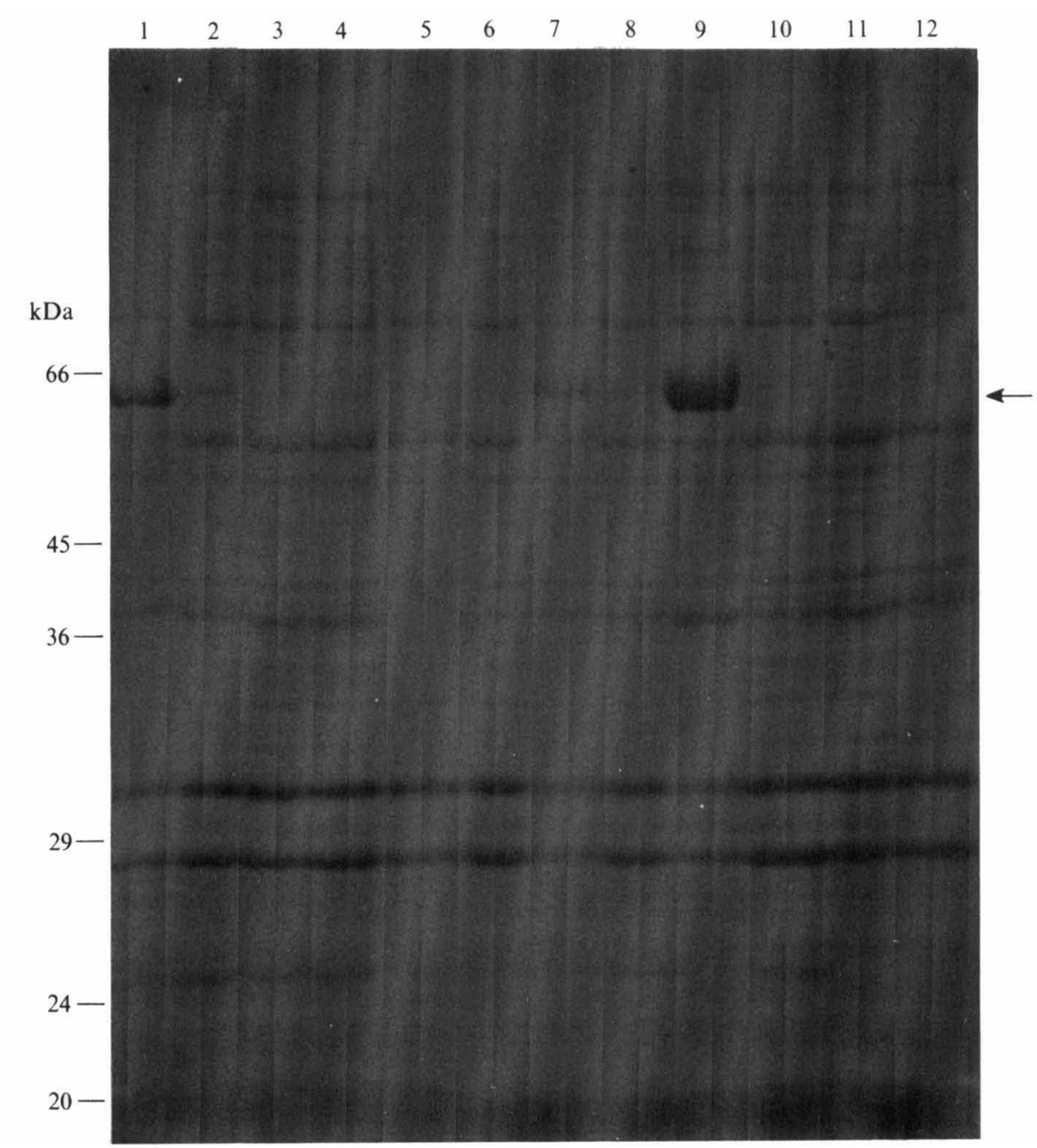

Fig. 4 SDS-PAGE of klebicins. The migration of the molecular mass markers used and their molecular masses ( $\mathrm{kDa})$ are indicated by lines on the left-hand side. The band corresponding to the klebicins is indicated by an arrow. Total cell proteins were prepared from cultures of $K$. pneumoniae UNF5023 carrying pRJ157 (lanes 1 and 2); pRJ157::Tn1000 (lanes 3 and 4); pRJ155 (lanes 5 and 6); pRJ155::Tn1000 (lanes 7 and 8); pJN73 (lanes 9 and 10); and no plasmid (lanes 11 and 12). In the lefthand lane of each pair the culture was grown in the presence of $\mathrm{MC}\left(0.5 \mu \mathrm{g} \mathrm{ml}^{-1}\right)$; in the right-hand lane of each pair the culture was grown in the absence of MC.

identical. Nucleotide sequencing of the klebicin A2-P5 structural gene and the immunity gene would allow a detailed comparison with that published previously for colicin E3 (Mock et al., 1983; Masaki \& Ohta, 1985). Recombinant plasmids which carried the colicin E5, colicin E8 or colicin E9 immunity gene did not confer any immunity to the group A klebicins (data not shown).

\section{Transfer of the btuB gene to Klebsiella}

$K$. pneumoniae strains are insensitive to $\mathrm{E}$ colicins, presumably because they lack the $b t u B$ receptor. The btuB gene of $E$. coli $\mathrm{K} 12$ has been cloned in pBR322, yielding the recombinant pKH3-8 (Heller et al., 1985). When $K$. pneumoniae UNF5023 was transformed with pKH3-8 DNA all $\mathrm{Ap}^{\mathrm{R}}$ transformants tested, unlike $K$. pneumoniae UNF5023 itself, were sensitive to colicins E3, E6 and E8. They were also sensitive to phage BF23, which uses the btuB gene 
product of $E$. coli as a receptor (Buxton, 1971). This implies that, with the exception of the $b t u B$ receptor, $K$. pneumoniae cells contain all the machinery for the uptake of E colicins and BF23 bacteriophages.

\section{Homology between klebicin A plasmids}

A comparison of the restriction maps of the three klebicin A plasmids reveals few common sites, with the exception of the $1.5 \mathrm{~kb} \mathrm{BamHI}$ fragment of pP5a and pP5b, both of which include at least part of the coding sequence of their respective klebicin structural genes. This is in contrast to the considerable restriction site homology observed between members of the $\mathrm{E}$ group of colicin plasmids (Watson et al., 1985; Chak \& James, 1986), and prevents any alignment of their restriction maps based upon common restriction sites. The molecular masses of klebicins A2-P5 and A3-P3 appear to be almost identical to that of cloacin DF13 as judged by SDS-PAGE (Fig. 4). The identification of the bands corresponding to klebicins A2-P5 and A3-P3 was assisted by a comparison of the total cell proteins of cultures of $K$. pneumoniae UNF5023 carrying klebicin-encoding plasmids, after growth in the presence and absence of $\mathrm{MC}$. The bands which corresponded to the presumptive klebicins A2-P5 and A3-P3 were missing from total cell proteins derived from cultures carrying plasmids pRJ155 and pRJ157 with Tn 1000 inserts which inactivate the respective klebicin structural genes.

In order to investigate further the homology between klebicins A2-P5 and A3-P3 we did some preliminary experiments with a hybridization probe consisting of the $1.5 \mathrm{~kb} \mathrm{BamHI}$ fragment of pRJ155. This fragment, which must encode a considerable part of the klebicin A2-P5 structural gene but does not include the E3imm gene (Fig. 2), hybridized to the $5.7 \mathrm{~kb} \mathrm{BamHI}$ fragment of pRJ157 but did not hybridize with pUC18 or pUC19 (data not shown). The $5.7 \mathrm{~kb}$ BamHI fragment of pRJ157, which consists of the $3 \mathrm{~kb}$ HindIII-BamHI fragment of pRJ157 plus the $2.7 \mathrm{~kb}$ vector (Fig. 3), includes a significant part of the klebicin A3-P3 structural gene. The $1.5 \mathrm{~kb}$ BamHI probe also hybridized with both Pst I fragments of pRJ157. These results imply considerable homology between the klebicin A2-P5 and the klebicin A3-P3 structural genes. A detailed comparison of the nucleotide sequences of these three plasmids will be invaluable in elucidating their evolutionary relatedness. It will be particularly interesting to compare the nucleotide sequence of the E3imm gene of pP3 with that of the klebA3-P3imm gene of the same plasmid to look for signs of divergent evolution after a gene duplication event. An understanding of the genetic organization and regulation of the three klebicin operons will also be of value in obtaining high titre extracts of these klebicins for use in a klebicin typing scheme (Cooper \& James, 1985).

This research was funded by a generous grant from Corning Biomedical Research, Boston, USA. We are grateful to K. Chak, R. Kadner, M. Lawrence and M. Mock for making recombinant plasmids constructed by them available to us for this work, and also to Jill Debbage and Lynne James for excellent technical assistance.

\section{REFERENCES}

ANDReoli, P. M., OVerbeeke, N., VeltKamp, E., EMBden, J. D. A. \& NiJKAMP, H. J. J. (1978). Genetic map of the bacteriocinogenic plasmid CloDF 13 derived by insertion of the transposon Tn901. Molecular and General Genetics 144, 159-170.

BIRnBoIm, H. C. \& Doly, J. (1979). A rapid alkaline extraction procedure for screening plasmid DNA. Nucleic Acids Research 7, 1513-1523.

BuXTON, R. S. (1971). Genetic analysis of Escherichia coli $\mathrm{K} 12$ mutants resistant to bacteriophage BF23 and the E-group colicins. Molecular and General Genetics 113, 154-156.

CHAK, K.-F. \& JAMES, R. (1984). Localization and characterization of a gene on the ColE3-CA38 plasmid that confers immunity to colicin E8. Journal of General Microbiology 130, 701-710.
ChaK, K.-F. \& JAmes, R. (1985). Analysis of the promoters for the two immunity genes present in the ColE3-CA38 plasmid using two new promoter probe vectors. Nucleic Acids Research 13, 25192531 .

ChaK, K.-F. \& James, R. (1986). Characterization of the ColE9-J plasmid and analysis of its genetic organization. Journal of General Microbiology 132, $61-71$.

COOPER, P. C. \& JAMES, R. (1984). Two new E colicins, E8 and E9, produced by a strain of Escherichia coli. Journal of General Microbiology, 130, 209-215.

COOPER, P. C. \& JAMES, R. (1985). Three immunity types of klebicins which use the cloacin DF13 receptor of Klebsiella pneumoniae. Journal of General Microbiology 131, 2313-2318. 
Di Masi, R. D., White, J. C., Schnaitman, C. A. \& BradbeER, C. (1973). Transport of vitamin B12 in $E$. coli: common receptor sites for vitamin $\mathrm{B} 12$ and the $E$ colicins on the outer membrane of the cell envelope. Journal of Bacteriology, 115, 566-573.

Edmondson, A. S. \& CoOKe, E. M. (1979). The development and assessment of a bacteriocin typing method for Klebsiella. Journal of Hygiene 82, 207223.

GUYer, M. S. (1978). The $\gamma \delta$ sequence of $F$ is an insertion sequence. Journal of Molecular Biology 126, 347-365.

Hakkaart, M. J. J., VeltKamp, E. \& NiJkamp, H. J. J. (1981). Protein $\mathrm{H}$ encoded by plasmid CloDF 13 involved in lysis of the bacterial host. Molecular and General Genetics 183, 318-325.

Heller, K., ManN, B. J. \& Kadner, R. J. (1985). Cloning and expression of the gene for the vitamin B12 receptor protein in the outer membrane of Escherichia coli. Journal of Bacteriology 161, 896-903.

HeRsChmaN, H. R. \& HelinSKi, D. R. (1967). Comparative study of the events associated with colicin induction. Journal of Bacteriology 94, 691699.

JAKes, K. S. \& Zinder, N. D. (1984). Plasmid ColE3 specifies a lysis protein. Journal of Bacteriology 157 , 582-590.

LAEMMLI, U. K. (1970). Cleavage of structural proteins during the assembly of the head of bacteriophage T4. Nature, London 227, 680-685.

LaU, P. C. K., Rowsome, R. W., Watson, R. J. \& VISENTIN, L. P. (1984). The immunity genes of colicin E2 and colicin E8 are closely related. Bioscience Reports 4, 565-572.

LAWRENCE, G. M. P. (1984). Characterization of the ColE8-J plasmid. PhD thesis, University of East Anglia.

LAWRENCE, G. M. P. \& James, R. (1984). Characterization of the ColE8-J plasmid, a new member of the group E colicin plasmids. Gene 29, 145-155.

Males, B. M. \& Stocker, B. A. D. (1982). Colicins E4, E5, E6 and A and properties of btuB $B^{+}$colicinogenic transconjugants. Journal of General Microbiology 128 , 95-106.

Maniatis, T., Fritsch, E. F. \& Sambrook, J. (1982). Molecular Cloning: A Laboratory Manual. Cold Spring Harbor, NY: Cold Spring Harbor Laboratory.

MASAKI, H. \& OHTA, T. (1985). Colicin E3 and its immunity genes. Journal of Molecular Biology 182, 217-227.
Miller, J. H. (1972). Experiments in Molecular Genetics. Cold Spring Harbor, NY: Cold Spring Harbor Laboratory.

Mock, M., Miyada, C. G. \& Gunsalus, R. P. (1983). Nucleotide sequence for the catalytic domain of colicin E3 and its immunity protein. Evidence for a third gene overlapping colicin. Nucleic Acids Research 11, 3547-3557.

Mock, M., Miyada, C. G. \& Collier, R. J. (1984). Genetic analysis of the functional relationship between colicin E3 and its immunity protein. Journal of Bacteriology 159, 658-662.

Oudega, B., Oldenziel-Werner, W. J. M., KlaAsenBoor, P., Rezee, A., Gla, J. \& de GraAf, F. K. (1979). Purification and characterization of cloacin DF13 receptor from Enterobacter cloacae and its inactivation with cloacin DF13 in vitro. Journal of Bacteriology 138, 7-16.

Ozeki, H., Stocker, B. A. D. \& Smith, S. M. (1962). Transmission of colicinogeny between strains of Salmonella typhimurium grown together. Journal of General Microbiology 28, 671-687.

Pugsley, A. P. \& Schwartz, M. (1983). A genetic approach to the study of mitomycin induced lysis of Escherichia coli $\mathrm{K} 12$ strains which produce colicin E2. Molecular and General Genetics 190, 366372.

Shafferman, A., Flashner, Y. \& Cohen, S. (1979). ColE1 DNA sequences interacting in cis, essential for mitomycin $\mathrm{C}$ induced lethality. Molecular and General Genetics, 176, 139-146.

Suit, J. L., Fan, M.-L. J., Sabik, J. F., Labarre, R. \& LURIA, S. E. (1983). Alternative forms of lethality in mitomycin $\mathrm{C}$-induced bacteria carrying ColE 1 plasmids. Proceedings of the National Academy of Sciences of the United States of America 80, 579583.

VAN TIEl-MenkVeld, G. J., OUdega, B., Kempers, $O$. \& DE GRAAF, F. K. (1981). The possible involvement of the cloacin DF13 receptor protein in the hydroxamate-mediated uptake of iron by Enterobacter cloacae and Escherichia coli (ColV). FEMS Microbiology Letters 12, 373-380.

Watson, R., Rowsome, W., TSAo, J. \& Visentin, L. P. (1981). Identification and characterization of Col plasmids from classical colicin E-producing strains. Journal of Bacteriology 147, 569-577.

WATSON, R. J., Vernet, T. \& Visentin, L. P. (1985). Relationships of the Col plasmids E2, E3, E4, E5, E6 and E7: restriction mapping and colicin gene fusions. Plasmid 13, 205-210. 